\title{
整形外科領域における日和見感染の症例について
}

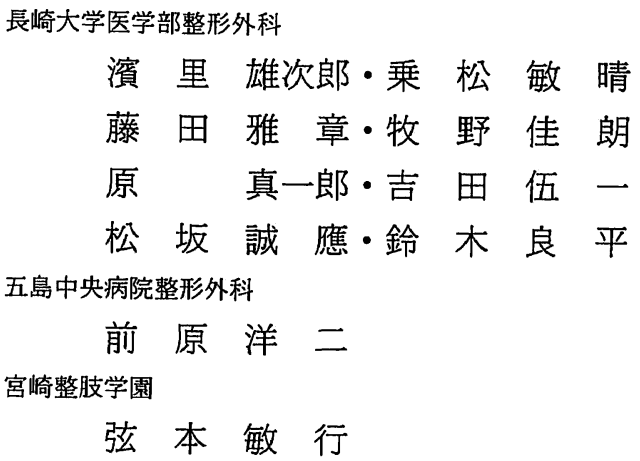

\section{Opportunistic Infection in tne Orthopedic Field}

by

\section{Yugirou Hamasato, Toshiharu Norimatsu, Masaki Fujita, Yoshirou Makino, Shinichiro Hara, Goichi Yoshida, Nobuou Matsusaka, Yoji Maehara, Toshiyuki Tsurumoto and Ryohei Suzuki \\ Department of Orthopedic Surgery, School of Medicine, Nagasaki University}

Tow cases, which might have been opportunistic infection in the early post-operative state, are reported in this paper.

Case 1, a 60-year-old male, developed spticemia on the 22nd day after a synovectomy for suppurative arthritis of the left knee. He had a 13 years history of steroid medication following pituitary adenoma resection.

Case 2, a 60-year-old, female, developed pueumonia 4 days after T.K. R.. The bacillus involved was strongly suspected to be a Legionella pneumophila. This patient's basic disease was rheumatoid arthritis.

These two cases had similarities of situation, for example their general condition before the onset of infection and antibiotic medication after the operationo; these infections took a similar course. The number of aged patients who have complications following operations for basic diseases has been increasing in the orthopaedic field. We must always, therefore, pay attention to the possibility of the opportunistic infection in the management of such cases.

\section{は じめに}

日和見感染とは，本来強い病原性を持たない常在菌 や外来菌による感染と定義されており，現在，各科に おいて本症が問題視されて来ている. 整形外科におい ても，当然本症は発症しているものと思われるが，診 断の困難さなどのために, 曖昧視されて来た感がある. 今回われわれは，術後に発症した日和見感染と考えら
れる 2 症例を経験したので，報告する．

症例

症例 1 ：大正 13 年 1 月 17 日生まれ，男性.

昭和 46 年に下垂体腺腫摘出術を受け, その後, 現在 までステロイド剤を投与されている。昭和 59 年 6 月頃, 左膝関節部の腫脹, 疼痛があり, 関節穿刺にて, 多量 の排液があった。化膿性膝関節炎が疑われ，抗生物質 
が投与された後，昭和 59 年 12 月 6 日，滑液膜切除術 を受けた。細菌学的には，菌は証明されず，組織学的 にも, 积極的に感染を示唆する所見は得られなかった。 術後の経過を図 1 に示すが, 術後 4 日目の発熱は, 薬 版過敏症によるものと考えられた。局所的にも，経過 は順調であったが, 術後 28 日目に抗生剂を中止したと ころ, 著しい発熱があった。呼吸器, 尿路の感染は否 定されたが，動脈血培䔶では，弱毒菌である Bacillus が大歨に検出された，以後，当院内科において，検査 および治療をうけることになったが, 発熱の起炎菌が 同定されないまま退院した.

症例 $2:$ 大正 13 年 2 月 1 日生まれ，女性.

昭和 53 年頃より RA が発症, 次第に進行して, 昭和 56 年頃よりは, 下肢の疼痛のため, 歩行不能となった。 昭和 59 年 6 月 5 日, 手術目的で当科に入院したが, こ の次点では，ステロイド郕は投与されていなかった。 昭和 59 年 6 月 21 日, 滕関節全置換術を受け, 術後 Piperacillin 1 日 $3 \mathrm{~g}$, Cefotiam 1 日 $4 \mathrm{~g}$ を投与され た. 術後, 局所的にも全身的にも経過は順調と思われ たが，術後 4 日目に，呼吸困難・発熱・頻脈があり， 胸部レントゲン写真上でも，肺炎の所見が見られるよ うになった(図 2)。内科医により,レジオネラ感染症 が疑われ, Minocycline が投与され，2 日後に解熱，4 日後には胸部レントゲン写真上の陰影も消失した（図 3，4). 血液, 喀痰, 尿および手術部位などからは, 菌は同定されなかった，その後の経過は順調で, 昭和 59 年 7 月 27 日に退院した.

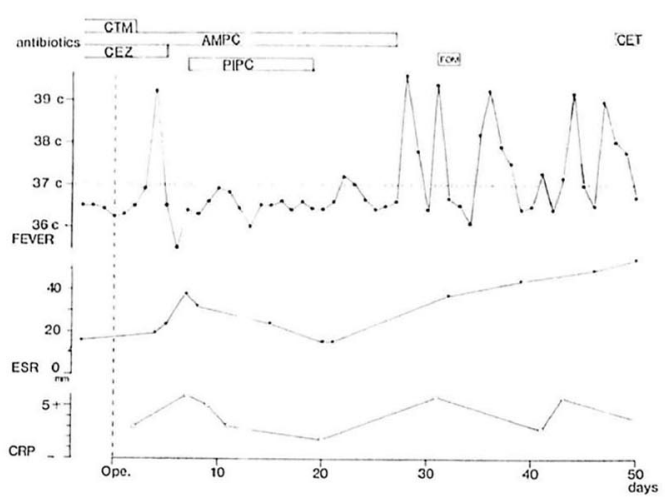

図 1 症例 $1: 60$ 才, 男性. 化價性㯟関節炎の診断で 滑液膜切除術をうけた。

術後 4 日目には薬剮感受性, 28 日目には日和見 感染によると思われる発熱があった。

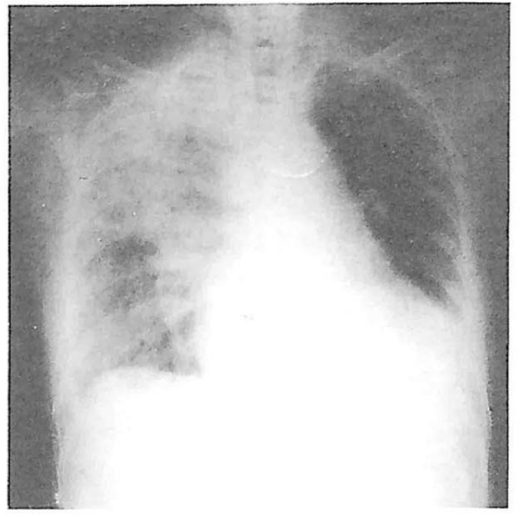

図 2 症例 2 の術後 4 日目の胸部レントゲン写真. 右 肺野に肺炎と思われる陰影がある。

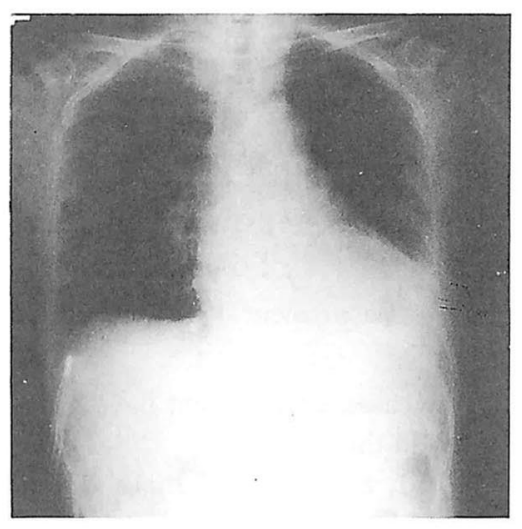

図 3 症例 2 の Minocyclone 使用後 4 日目の胸部レ ントゲン写真. 右肺野の陰影は消失している.

考

察

症例 1 , 症例 2 に共通することは, いずれも 60 才を 超えた高令者であるということ，全身的因子として， 症例 1 は長期のステロイド使用, 症例 2 は RA により, 兔疫能が正常ではなかったと考えられること, 術後に 大量の抗生郕が投与されていること, 明らかな起炎菌 の同定ができなっかたこと, 抗生剤を他剤に変更する ことによって軽快したことなど, 多くの共通点を持っ ている (表 1 ).

日和見感染は, 何らかの原因で常在細菌裳が乱され たり,宿主の抵抗が減弱した場合に発症する1わけであ るが, この 2 例においてもこのような発症の背景は, 十分に整っていたといえる.整形外科領域においては, 高令者を対照とする手術も決して少くない，また，最 


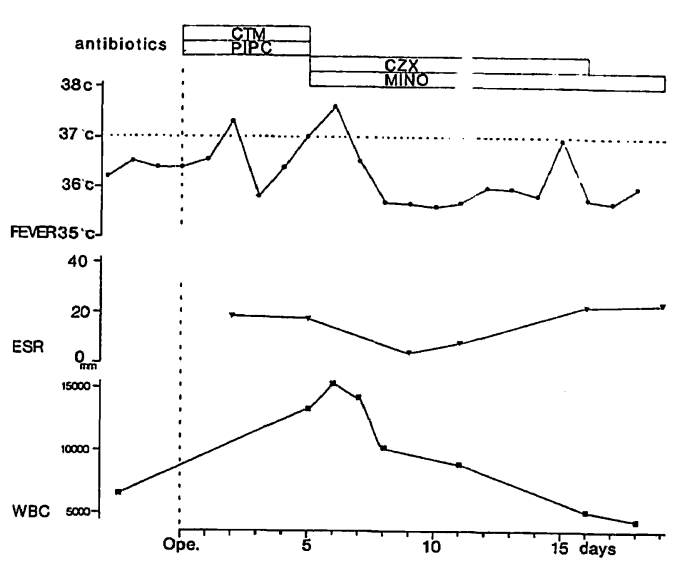

図 4 症例 2:60才, 女性. RA の診断で膝関節全置 換術をうけた。

術後 4 日目より, 呼吸困難, 発熱, 頻脈が出現, レジオネラ感染症が疑われた。

近では，異物を用いた人工関節置換術などが，さかん に行われるようになってきたので, 感染予防のために, 術後は大量の抗生剂が使用されているのが現状である2. 症例 1 においては，化膿性膝関節炎を疑われたための 抗生剤に加えて, 術後の抗生剤の使用が菌交代症をひ き起こしたと考えられるが，それが日和見感染である と確定するには，いささか問題があるかも知れない. しかし, 宿主には, ステロイド阂の長期投与による防 御機構の低下があり，それを背景として Bacillusによ る日和見感染がおこった可能性が高いと判断した. 症例 2 は, 斉藤ら
染としてのレジオネラ感染症を疑うに十分な臨床所見, X線学的所見, および検查所見として挙げられている もののうち, 発熱, 胸痛, 呼吸器症状, sGOT の上昇, 胸部レントゲン写真上の肺炎像の進行が速いことなど がそろっており，本症例は，日和見感染症としての典 型的な症例であると思われる.

日和見感染症の診断は, 原・斉藤らも指摘している ごとく"，困難なことが多いとされている，それは, 治 療の困難さとなって現われてくるわけであるが，とく に整形外科領域においては, 術後の経過中に, 発熱を 伴った異常な所見があれば，局所感染とともに，本症 を疑うべきであろう.

$$
\text { ま と め }
$$

術後の経過中に発症した日和見感染と思われる 2 症 例を報告する。

症例 1 は 60 才の男性で, 化膿性膝関節炎に対する滑 液膜切除術を受け, 術後 28 日目に, Bacillusによると 思われる敗血症が発症した。本症例は，以前に下垂体 腺腫摘出術を受け, 13 年間ステロイド剂が投与されて いた.

症例 2 は 60 才の女性で, 膝関節全置換術を受け, 術 後 4 日目に肺炎が発症し, 臨床所見, レントゲン写真 所見および検查所見より,レジオネラ感染症がもっと も強く疑われた. 本症例には, 基礎疾患として RA が あった。

以上の 2 症例には, 発症前の全身状態, 術後の抗生 剤の使用, 発症後の経過などに, 多くの共通点が見ら

表 1 症例 1 と症例 2 の比較

\begin{tabular}{c|c|c}
\hline & Case 1 & Case 2 \\
\hline Age & 60 yrs. & 60 yrs. \\
\hline Primary disease & Supprativive arthritis & RA \\
\hline Operative method & Synovectomy & TKR \\
\hline Antibiotics after ope. & CEZ AMPC PIPC & CTM PIPC \\
\hline Date of fever & 28 days after ope. & 4 days after ope. \\
\hline Opportunistic infection & Sepsis & Pneumonia \\
\hline Organisms & Bacillus & Unknown \\
\hline Chemotherapy for infection & CET & MINO \\
\hline Prognosis & Good & Satisfactory \\
\hline
\end{tabular}


れた。整形外科領域においても，基碗疾患を持つ高令 者の手術も增加している現状であり，このような日和 見感染症の存在を，常に念頭においておく必要がある であろう。

文献

1）上井一輝・他：整形外科領域における術後感染予防 に対する抗生物質の選択. Jpn. J. Antibiot., $38 ： 83$ -
94, 1983.

2）原 耕平：opportunistic infection としてみた在郷 軍人病。臨床医, $8: 1042-1047,1982$.

3）石引久彌·他：術後感染症. 治療, 67：855-860, 1985.

4）斎藤 厚：opportunistic infection における在郷軍 人病の診断.クリニカ, $10: 829-834,1983$.

5） 戸田忠雄·他：戸田細菌学。南山堂, 東京都， 1980.

6）和田野安良：培養菌陰性の感染症. 臨整外, 18：991 $-996,1983$. 